\title{
The reproduction of some Phyllostomidae (Chiroptera) from the Northwestern region of the State of São Paulo
}

\author{
VALDIR ANTONIO TADDEI \\ Departamento de Zoologia - Faculdade de Filosofia, Ciências e Letras \\ 15.100 - São José do Rio Preto - Estado de São Paulo - Brasil
}

\section{R E S U MO}

A reprodução dos Phyllostomidae foi estudada examinando-se 1558 exemplares, obtidos no período de 1967 a 1972. Não existe uma estação sexual bem definida para 9 das 16 espécies registradas. Os dados disponíveis para 7 espécies não permitiram conclusões a este respeito, porém, uma delas, Chiroderma v. villosum, aparentemente acompanha o padrão das espécies com atividade sexual não limitada a um período curto.

Os períodos de aumento ou diminuição da incidência de gestações, sugerem a existência de dois ciclos, um principal com gravidez incipiente, em junho-julho e recém-nascidos em outubro-novembro e outro secundário, em continuidade, com nascimentos em fevereiro-março. O maior número de recém-nascidos do ciclo principal ocorre no início da estação chuvosa e quente, de outubro a março, e os nascidos provenientes do ciclo secundário, no final dessa estação.

Nos meses mais secos e mais frios, de junho e julho, observou-se ausência ou uma porcentagem mínima de fêmeas lactantes.

Para as espécies estudadas, o tempo de gestação estimado foi superior a três meses e meio. Observou-se sempre um embrião por gestação, apesar de terem sido ncontradas condições que poderiam sugerir a existência de mais do que um embrião.

\section{A B S T R A C T}

Reproduction in the Phyllostomidae was studied through an examination of 1558 specimens collected from 1967 to 1972 . The absence of a well defined sexual season was observed for 9 of the 16 species studied. The data available for 7 of the species do not permit conclusions as to the duration of the sexual season. However, one of these, Chiroderma v. villosum, apparently follows the pattern of those species having a sexual season not restricted to a brief period. 
The periods of increase or decrease in the incidence of gestations suggest the existence of two cycles: a major cycle with females in incipient stages of pregnancy in June-July with new-borns in October-November, and a secondary cycle, continuous with the first, with new-borns in February-March. The peak number of the major cycle coincides with the initiation of the warm, rainy season occurring in October to March, and the births resulting from the secondary cycle occur in the end of this season.

An absence or minimal percentage of lactant females was observed in the drier and cooler months of June and July.

For the species studied, the gestation period was estimated to exceed $31 / 2$ months. Although conditions were observed which could suggest the existence of more than a single embryo, without exception, one embryo per gestation was observed.

\section{N T R O D U C T I O N}

Studies of the reproduction of Tropical American bats permitted Tamsitt and Valdivieso $(1963 a$ : $104 ; 1965$ : 150) to recognize two groups. One in which the species have a restricted sexual period with inhibitions caused directly or indirectly by climatic conditions unfavorable to continuous procreation. The existence of periodocity in the reproduction of tropical mammals is still debated. Pirlot (1967) takes into consideration the considerable variability of climatic data, particularly in the intertropical regions in which distinct dry and humid seasons occur. In such regions temperature and humidity together can interrupt the continuity of reproductive activity in numerous species of mammals, even if these interruptions are not total, long, or regular. Among those species which have a restricted sexual period are found Noctilio labialis minor - Noctilionidae, in Panama (Anderson and Wimsatt, 1963); Myotis n. nigricans - Vespertilionidae, in Ecuador (Tamsitt and Valdivieso, 1963); Glossophaga s. soricina - Phyllostomidae, in Mato Grosso, Brazil (Hamlett, 1935), which Tamsitt and Valdivieso (1963a: 104; 1964: 401; 1965: 150) include with doubts in this category and Histiotus velatus - Vespertilionidae, in Rio de Janeiro, Brazil (Peracchi, 1968). In the second group the species lack a well defined sexual period and reproduce throughout the year. This is documented by the capture of non-pregnant, pregnant and lactating females, and mature and immature males throughout the year (Wimsatt and Trapido, 1952: 419). Among those species lacking a well defined sexual period are presently included Desmodus rotundus Desmodidae, in Panama (Wimsatt and Trapido, 1952) and in Mexico (Cockrum, 1955); the Phyllostomidae Artibeus jamaicensis, in Providence Island - Caraibas (Tamsitt and Mejia, 1962); Artibeus lituratus in Colombia (Tamsitt and Valdivieso, 1963a); Glossophaga soricina and Artibeus jamaicensis in Mexico (Cockrum, 1955); Phyllostomus discolor, Glossophaga s. soricina, Carollia p. perspicillata, Uroderma b. bilobatum and Artibeus lituratus palmarum, in Colombia (Tamsitt and Valdivieso, 
1964, 1965, 1965a) and Myotis nigricans - Vespertilionidae, in Panama (Wilson and Findley, 1970).

The study of South American Chiropterids is based primarily on works of a systematic nature and notes concerning the distributions of species. Biological data are rare and of the 120 species attributed to Brazil few have been analyzed from this perspective.

The object of this study is to contribute to a better knowledge of the reproductive activity of the Chiropterids which occur in the northwestern region of the state of São Paulo, attempting to determine the reproductive pattern in the family Phyllostomidae.

\section{THE REGION}

The region studied is composed of arenites of fluvial-lacustrine deposition (Arid, 1967) and is located between $49^{\circ} 00^{\prime}-51^{\circ} 35^{\prime} \mathrm{W}$ and $19^{\circ} 45^{\prime}-21^{\circ} 50^{\prime} \mathrm{S}$, with an approximate area of $31,750 \mathrm{Km}^{2}$ and elevations ranging from 280 to $600 \mathrm{~m}$ (Almeida, 1964: 256). The original vegetation, classified as low and fairly open wide-leafed forest, is today restricted to small areas dispersed among cultivated areas, young secondary forests invaded by ruderal species, and fields covered in part by xerophytic species (Marinis and Camargo, 1966).

Distribution of annual rainfall was not homogeneous throughout the year. There was a distinct rainy season with $85 \%$ of the annual total (from October to March) and a dry season, with only $15 \%$ of the annual total (from April to September).

The rainiest months were December, January, and February, with $53.71 \%$ of the total annual precipitation. The driest period occurred in the months of June, July, and August, with only $4.67 \%$ of the annual total, with August as the driest month, with only $1.2 \%$. The indices of annual precipitation always exceeded $1,000 \mathrm{~mm}$, with a mean of $1,152 \pm 50 \mathrm{~mm}$. The mean annual temperature varied around $25.4^{\circ} \mathrm{C}$. The highest mean temperatures, above $26.4^{\circ} \mathrm{C}$, were recorded from October to March and the lowest, with means above $21^{\circ} \mathrm{C}$, from April to September. The annual mean of maximums was $30^{\circ} \mathrm{C}$ and of minimums $20.8^{\circ} \mathrm{C}$ (Barcha and Arid, 1971: 109) (Fig. 1).

The Climate can be considered as warm and humid tropical with summer rains and winter droughts, of the AW type (cf. Koeppen in Setzer, 1966: 36).

\section{MATERIAL AND METHODS}

Between 1967 and 1972, 1558 specimens ( 732 males and 826 females) of Phyllostomidae were obtained, the majority from within an $80 \mathrm{Km}$ radius of the city of São José do Rio Preto. 


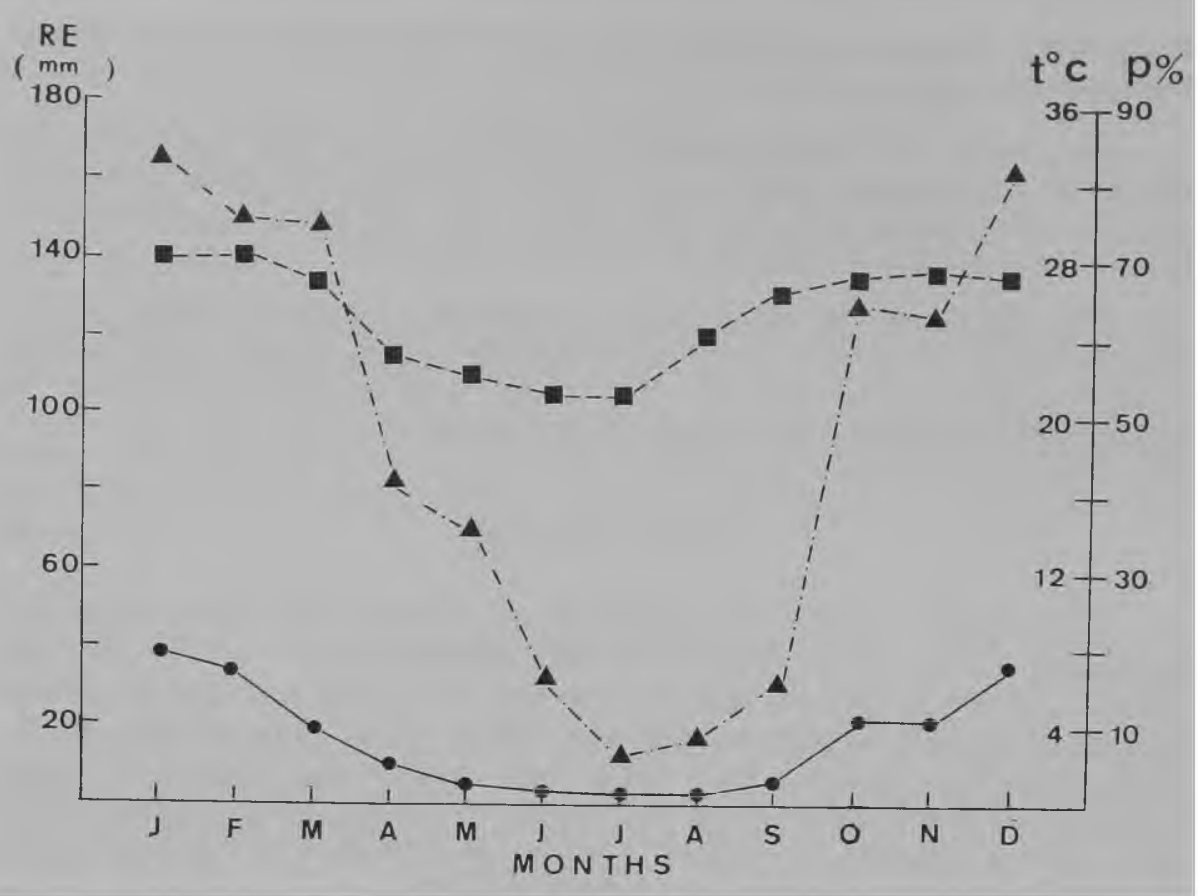

Fig. 1 - Annual variation of precipitation, temperature and real evapotranspiration in the northwestern region of the state of São Paulo. P\% $=$ Precipitation (- $) ; t^{\circ} \mathrm{C}=$ Temperature $(----) ; \mathrm{RE}=$ Real evapotranspiration $(-\cdot-\cdot-\cdot-)$.

The animals were collected during the day in their roosts by means of manual entomological nets and mist nets. For night collecting, mist nets were placed in possible lines of flight, near food sources or at roosts exits. The animals were collected throughout the year and analyzed in part by the method of Wimsatt and Trapido (1952) and Tamsitt and Valdivieso (1965, 1965a). Data were collected concerning fur, weight, and stage of ossification of the distal metaphyses of the femur, as well as some features of the reproductive system. In males the presence or absence of spermatozoa in the epididymis was observed by microscope in recently sacrificed animals. Parts of the female reproductive system were removed and fixed in Bouin or $10 \%$ formol. Serial sections of $10 \mu \mathrm{m}$ were made and stained with Harris' hematoxylin and eosin. This permitted the recognition of the functional stage of the ovaries and the existence of incipient pregnancy, if present.

A. Males

a - length and width of testes.

$b$ - absence of spermatozoa in the epididymis.

c - presence and relative quantity of spermatozoa in the epididymis. 
B. Females
a -- absence of an embryo.
b - presence, number, and measurements of embryos from initial implantation to completed development.
c - functioning of the mammary glands.
d - existence of sucklings.

The following categories were adopted in order to organize the present study as well as to facilitate the recognition of the various stages in which the specimens were observed to occur:

\section{A. Males}

a - Sucklings - characterized by direct dependency on the mother, size variable, with recurved styliform teeth, and furless in some species to with juvenile fur.

b - Group I - characterized by juvenile or transitory fur, metaphyses generally not ossified, small testes and reduced epididymis lacking spermatozoa.

c - Group II - specimens with transitory or adult fur, ossified metaphyses, testes generally poorly developed, and epididymis with rare of few spermatozoa.

d - Group III - specimens with adult fur, ossified metaphyses, testes generally well developed, epididymis swollen with large quantities of spermatozoa.

The degree of development of the testes and the presence or absence of spermatozoa in the epididymis, along with other characteristics, permits the recognition of adult males (Groups II and III) and their separation from juveniles (Group I). It is difficult to establish rigid limits to differentiate between adult males of Groups II and III, and the characteristic of the amount of spermatozoa in the epididymis should be considered with some reserves. However, the number of specimens in this condition was small and the data, despite the restrictions noted, permitted the establishment of periods during the year when the males are in a state of intense sexual activity.

B. Females

a - Sucklings - characterized by direct dependency on the mother, size variable, with recurved styliform teeth and furless, in some species, to with juvenile fur. 
b - Young - characterized by juvenile fur, frequently smaller in weight and size than adult females, uterus small in comparison with those of the adults, and metaphyses generally not ossified.

c - Non-pregnant adults - characterized by adult fur and completely ossified metaphyses.

d - Pregnant specimens (Group I) - characterized by incipient pregnancy with embryos exhibiting forearm lengths less than $25 \%$ of the mean length observed for adults. Females with developed embryos, therefore not in the stage of Group II, were treated separately from females with incipient pregnancy.

e - Pregnant specimens (Group II) — with embryos exhibiting forearm lengths equal to or greater than $25 \%$ of the mean adult length up to completely developed embryos.

$\mathrm{f}$ - Lactating specimens - with well developed, functioning nipples surrounded by a hairless region indicative of the activity of suckling young.

$\mathrm{g}$ - Pregnant-lactating specimens - with developed and functioning nipples, once again pregnant in the stage of Group I.

The stage of development of the ovarian follicles follows the classification of Wimsatt and Trapido (1952: 428).

\section{RESULTS AND DISCUSSION}

Collections were made in the period from 1967 to 1972 . The data of Barcha and Arid (1971) for the northwestern region of the state of São Paulo refer to the period from 1961 to 1970 and are the most adequate reference for the present study. Fig. 1 is based on the data of Barcha and Arid (1971) and gives curves for precipitation, temperature and real evapotranspiration. Since adjacent monthly indices closely approximate one another, bimonthly groupings are used in Table 1 and Figs. 2 to 5 .

In Table 1 the animals were arranged according to sex, stage of development, and reproductive activity. In accordance with the methods proposed, the following categories resulted: males (Group I, Group II, Group III); females (Young, Non-pregnant adults, Pregnant in initial stage of Group I, Group I in advanced stages, Group II, Lactating specimens). The distribution of pregnant-lactating specimens was made in the following manner. Since they occurred in the stage of Group I, they were included either in the groups of initial or advanced pregnancy, as well as in the group of lactating specimens. Consequently, each pregnantlactating specimen was counted twice. Thus the total was increased from 826 to 866 since forty females in this condition were collected. The number in parentheses refers to the number of females both pregnant and lactating.

Table 2 presents the number of males in the stage of group III and the months in which they were collected; Table 3 gives the number of 


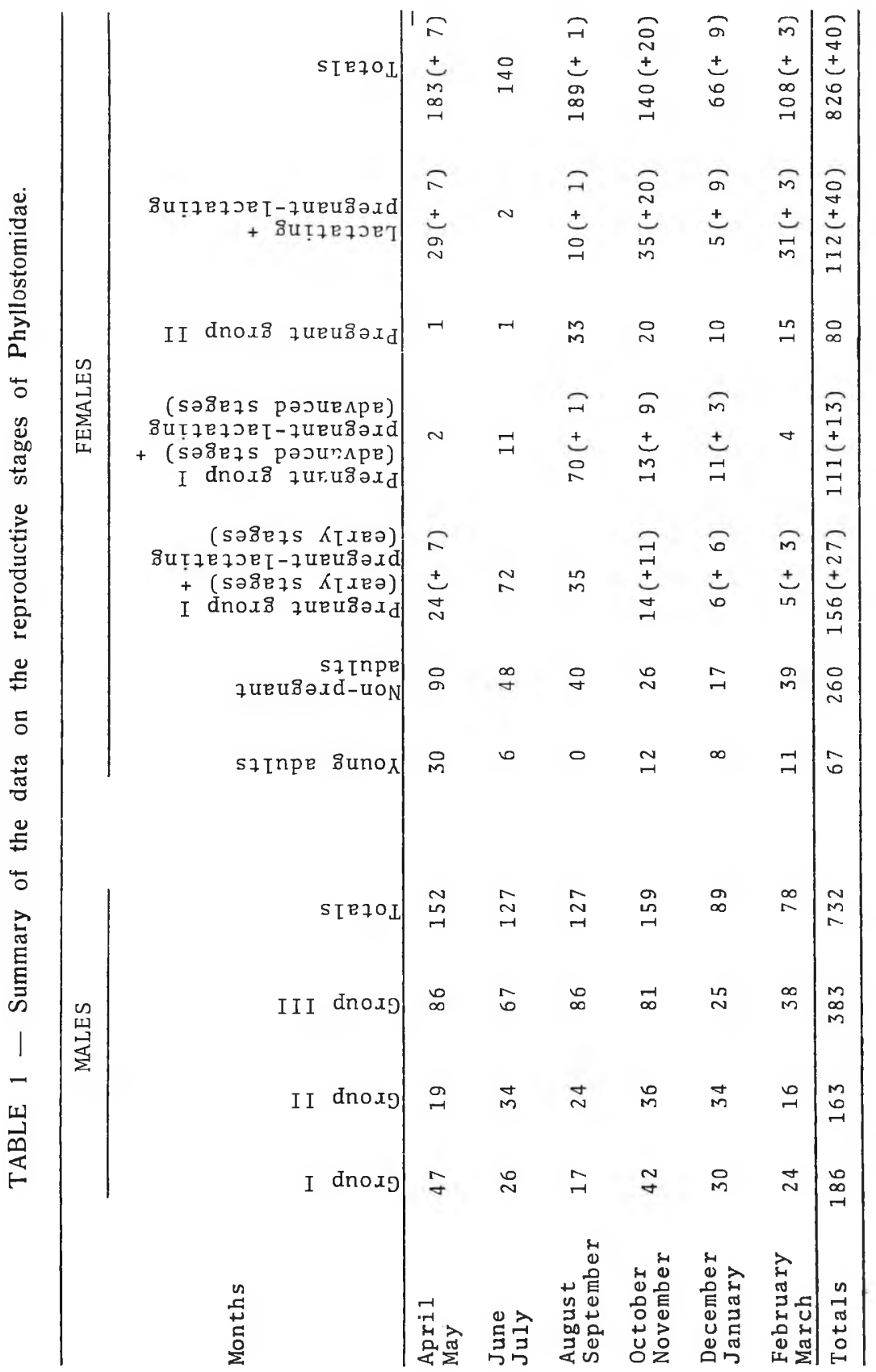




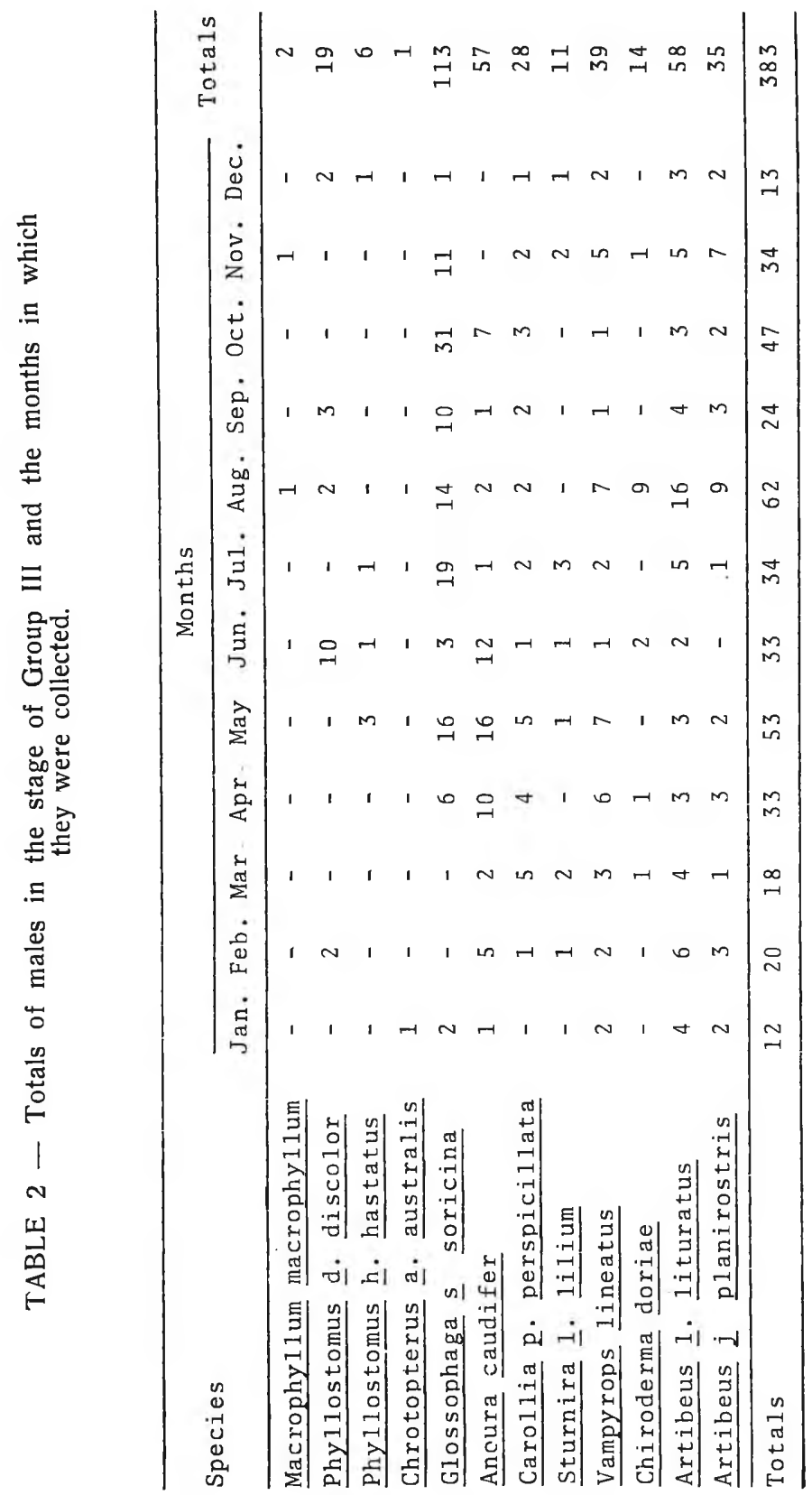




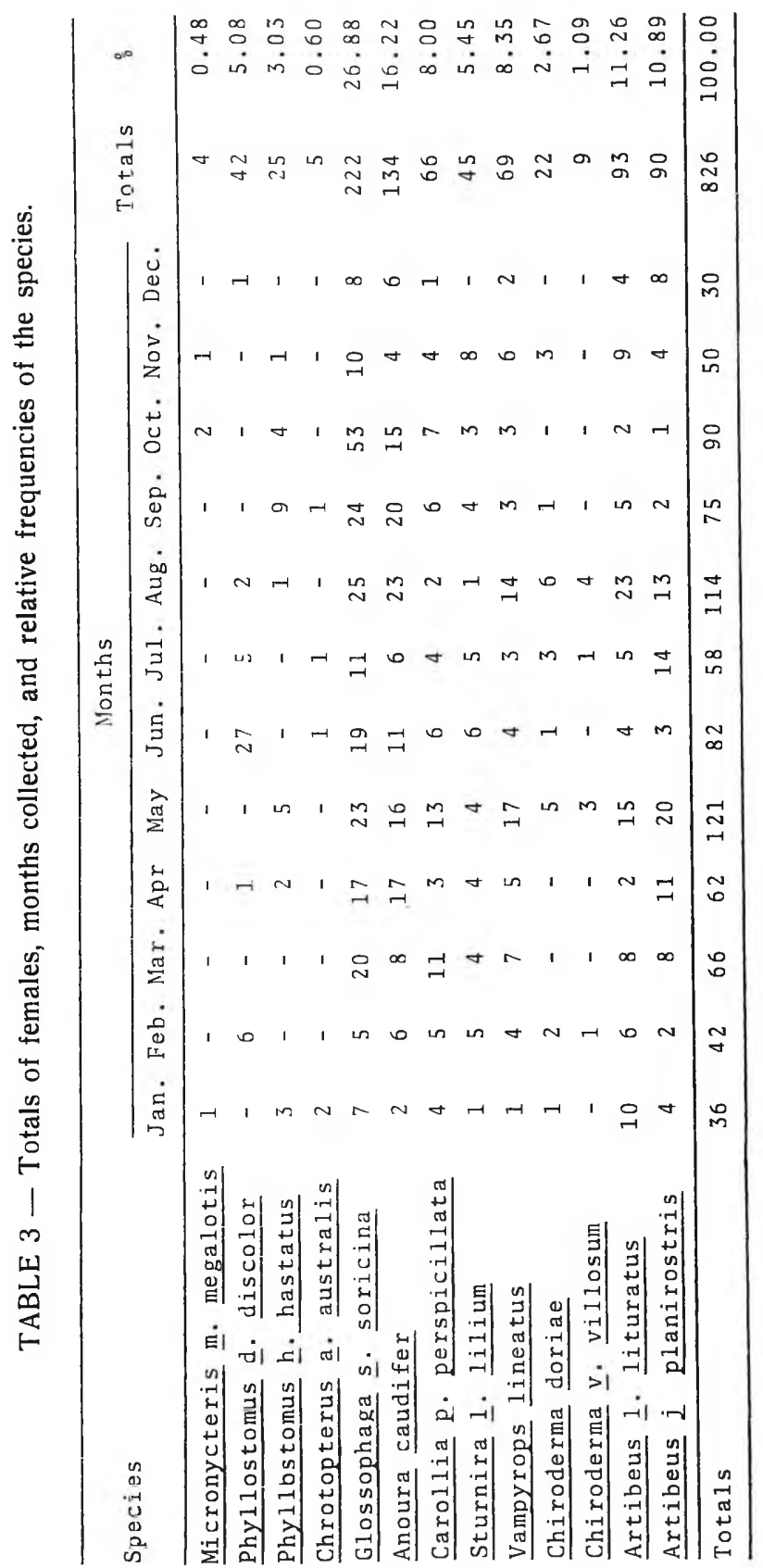


TABLE 4 - Total of specimens collected for each species and the percentage of the sexes.

\begin{tabular}{|c|c|c|c|c|}
\hline Species & Males & Females & Totals: & males \\
\hline Micronycteris m. megalotis & 8 & .4 & 12 & - \\
\hline Macrophyl1um macrophyl1um & 8 & 0 & 8 & - \\
\hline Phyllostomus d. discolor & 35 & 42 & 77 & 4545 \\
\hline Phyllostomus $\underline{\text { h. hastatus }}$ & 29 & 25 & 54 & 53.70 \\
\hline Chrotopterus a. australis & 2 & 5 & 7 &. \\
\hline Glossophaga s. soricina & 239 & 222 & 461 & 51.84 \\
\hline Anoura caudifer & 107 & 134 & 241 & 44.39 \\
\hline Carollia p perspicillata & 48 & 66 & 114 & 42.10 \\
\hline Sturnira 1 lilium & 35 & 45 & 80 & 43.75 \\
\hline Vampyrops lineatus & 65 & 69 & .134 & 4850 \\
\hline Vampyressa p pusilla & 2 & 0 & 2 & - \\
\hline Chiroderma doriae & 17 & 22 & 39 & 4358 \\
\hline Chiroderma $\underline{v}$ villosum & 2 & 9 & 11 & - \\
\hline Artibeus 1. 1ituratus & 76 & 93 & 169 & 44.97 \\
\hline Artibeus j. planirostris & 57 & 90 & 147 & 38.77 \\
\hline Pygoderma bilabiatum & 2 & 0 & 2 & - \\
\hline Totals & 732 & 826 & 1,558 & 46.98 \\
\hline
\end{tabular}

females collected, the distribution of the months in which they were collected, and the frequency of the species. Table 4 presents the percentage of sexes, omitting those species whose numbers collected were insufficient.

The graphs given in Figs. 2 to 5 were drawn using the data of Table 1 and by grouping together all the categories proposed. In Fig. 4 females of group I were separated depending on whether in initial or advanced pregnancy. In Fig. 5 young females were excluded and the percentages were calculated on the total number of adults obtained, thereby establishing the incidence of lactating and pregnant specimens. This graph was drawn following the same criteria adopted for Table 1, that is, counting each pregnant-lactating specimen as being both a pregnancy and as lactating.

The occurrence of continuous spermatogenesis was noted in the majority of the species as shown by the recording of males in intense sexual activity (group III) throughout the year (Table 2). Males with small quantities of spermatozoa (group II) and immature males (group I) were likewise obtained throughout the year. In August-September a minimum of males of group I were collected which coincides with a minimum number of female young collected from the same period.

Nearly $50 \%$ of the females collected in April-May were not pregnant. In June-July incipient pregnancies were more frequent, with an incidence 


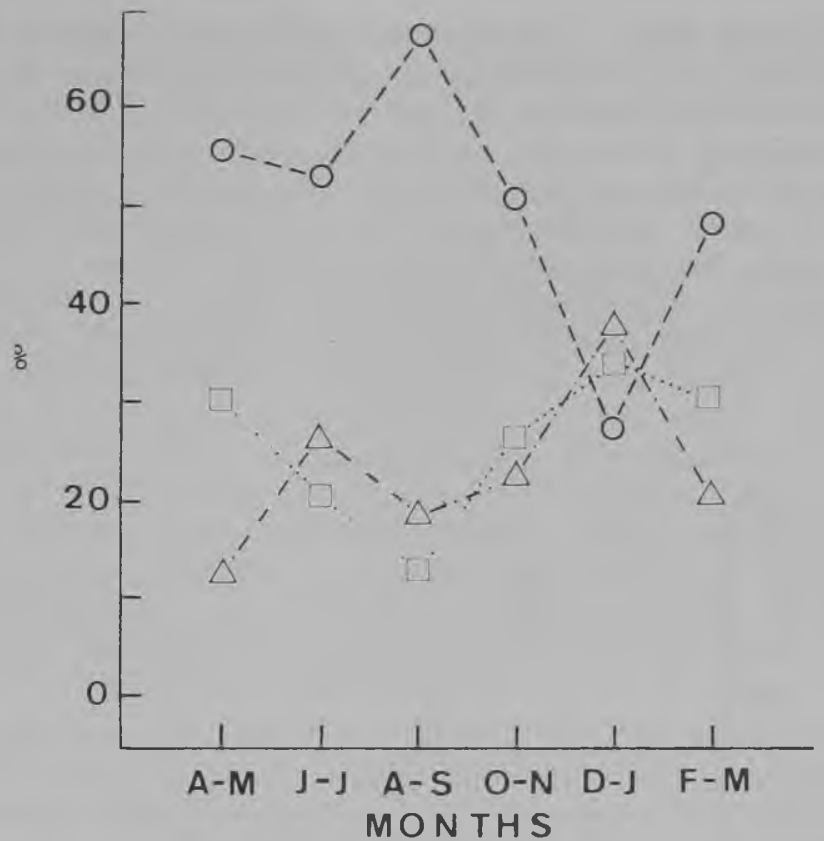

Fig. 2 - Relative frequencies of males in group I ( .), II $(-\cdot-\cdot-\cdot-\cdot)$ and III $(-----)$.

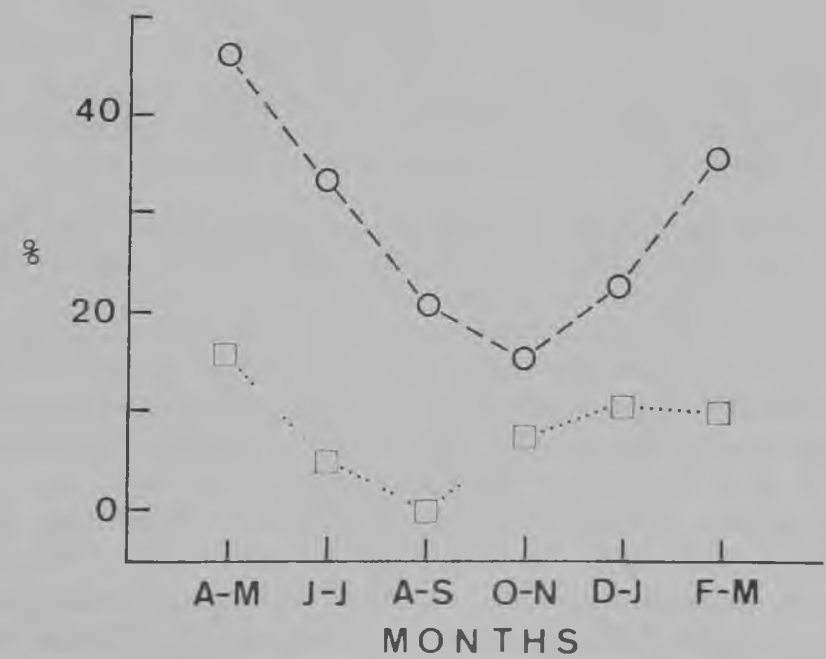

Fig. 3 - Relative frequencies of young females (. ) and non-pregnant adults $(-----)$. 
of fecundation over $50 \%$ The existence of this major period of fecundation in June-July was confirmed by the greater percentage of females of group I with developed embryos in August-September (Figs. 3 and 4).

Births recorded in the end of August were probably from females which conceived in months before June. The greatest number of births occurred in October and November which coincided with the greater number of females in advanced stages of gestation (group II) observed in August-September. The incidence of females of group II remained at the same level during the warm, rainy season (October to March), then dropped off to nearly zero at the beginning of the cold, dry season in April (Fig. 4).

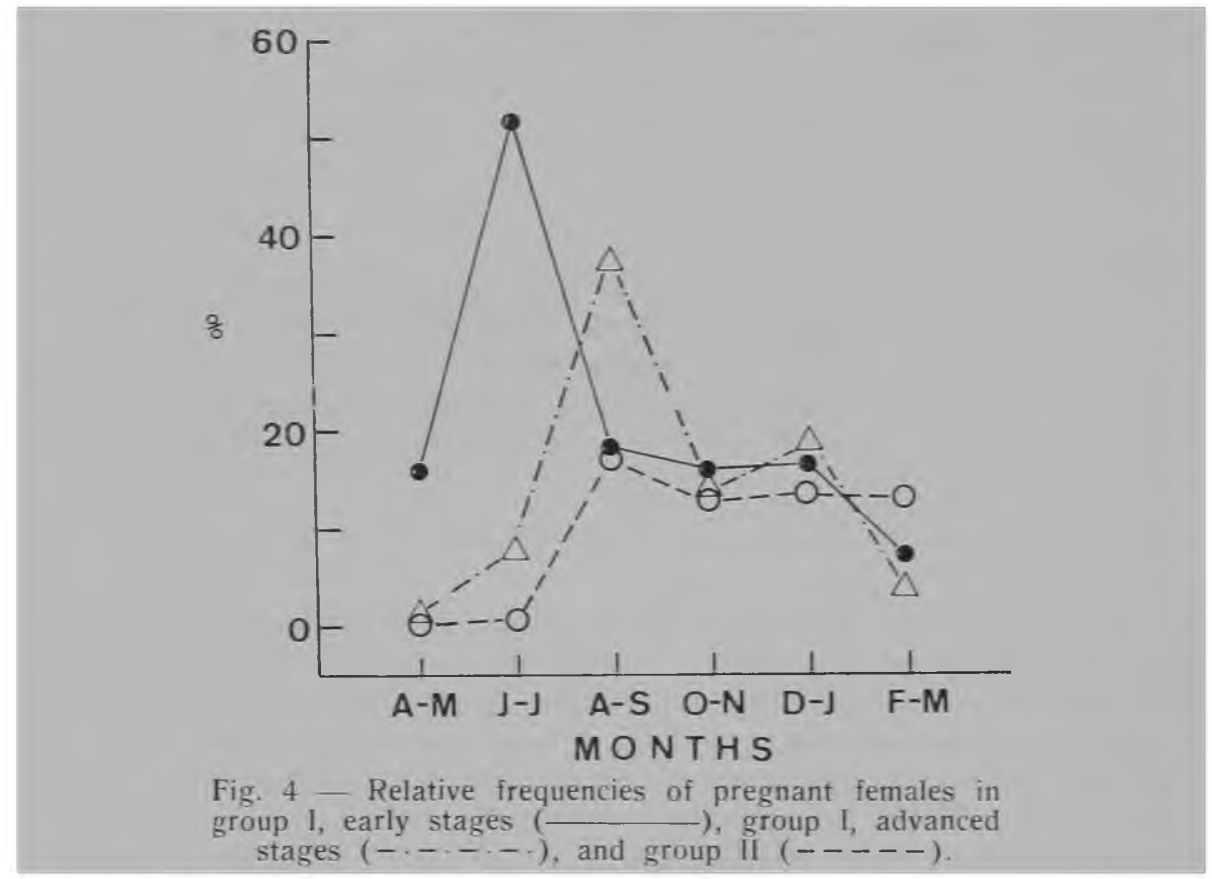

The greatest incidences of pregnant-lactating specimens was observed in November and December with $34.0 \%$ and $23.3 \%$ respectively. Along with these were collected pregnant females with mammaries regressing. Pregnant-lactating specimens were recorded in the following species: Glossophaga s. soricina, Anoura caudifer, Sturnira l. lilium, Vampyrops lineatus, Chiroderma doriae, Artibeus $l$. lituratus and Artibeus j. planirostris. Even during pregnancy the ovary remained functional with the possibility of new ovulation following birth. In bats, the post-partum estrus was described initially in Nycteris luteola - Nycteridae by Matthews (1939, Nature, 143: 643 in Matthews, 1941: 304). Since recurrent estrous periods occur during only a part of the year Wimsatt and Trapido (1952: 434) proposed the designation "seasonally polyestrous" for this species which differs from Desmodus rotundus which does not demonstrate a distinct sexual period. 
In the region studied failure to collect pregnant-lactating specimens occurred only in June, July, and September. The higher percentage recorded in November agreed with the higher percentage of females in early pregnancy recorded in June-July. It is therefore probable that these females initiated their reproductive cycle in June-July and were quickly entering a second pregnancy. Others initiated the cycle in October-November and a part of these again became pregnant in the following months, that is, during the first half of the year. The possibility of a third pregnancy following rapidly was suggested by Matthews (1941: 304) and Dwyer (1970: 409).

The criteria proposed by Wimsatt and Trapido (1952: 419) permitted the conclusion that of the 16 species studied, a well defined sexual period is lacking in Phyllostomus d. discolor, Glossophaga s. soricina, Anoura caudifer, Carollia p. perspicillata, Sturnira l. lilium, Vampyrops lineatus, Chiroderma doriae, Artibeus l. lituratus and Artibeus $j$ planirostris. As we have already noted, the reproductive pattern of some of these species has previously been studied in equatorial regions. We have, in part, corroborated the conclusions of these studies.

Our data was not sufficient to permit a sound interpretation of the reproductive period in the remaining species. Only a small number of male specimens were obtained of Macrophyllum macrophyllum, Vampyressa $p$ pusilla and Pygoderma bilabiatum. Data for Chronycteris $m$. megalotis, Phyllostomus $h$. hastatus and Chrotopterus a. australis revealed females in reproductive activity only in the second half of the year. Chiroderma $v$. villosum apparently accompanies the reproductive pattern of the species with an unlimited period, since females with the mammaries in regression were found once again pregnant in July and August.

Glossophaga s. soricina was studied in the state of Mato Grosso (Hamlett, 1935: 146) and was considered as having limited reproduction with a short period. We examined 461 specimens of Glossophaga $s$. soricina obtained in several years and failed to register pregnant females only in the months of April and May. Our data corroborate the conclusions of Cockrum (1955: 490) and Tamsitt and Valdivieso (1964: 400). The latter authors pointed out the possibility that a study of specimens from other months would demonstrate that in Glossophaga s. soricina reproduction is also continuous at his latitude, possibly culminating in the humid season. This has been confirmed in the present study.

In the study of 1558 specimens of bats during the course of this investigation, we verified that the lowest indices of incidence of gestation, below $30 \%$, occurred in February to May, that is, at the end of the rainy season in February-March and the initiation of the dry season in AprilMay (Fig. 5). These results differ from those obtained by Pirlot (1967) in Colombia and Venezuela where he registered the lowest indices, less than $30 \%$, during the warm, humid season in August to November.

The bimodal reproductive pattern described for the Phyllostomidae is similar to that of Myotis adversus - Vespertilionidae, studied in Australia at the latitude of $22^{\circ} 30^{\prime} \mathrm{S}$. This species revealed two principal periods of birth, one in the first half of September and the other from 
the middle of November to the middle of December, with an estimated gestation period of 75 to 90 days (Dwyer, 1970: 408).

Gestation time in the species studied is not known. According to Wimsatt and Trapido (1952: 423) the data available in the literature suggests some direct correlation between the length of gestation and the size of the animals and also reveals a tendency for gestation time to be longer in tropical species than in those of temperate zones. Thus Desmodus rotundus has a comparatively long gestation period for a bat of its size and requires at least 5 months. The opinion of these authors that the relatively large size of the fetus at birth suggests a long period of gestation was corroborated by Tamsitt and Valdivieso (1963: 104; 1965a: 159).

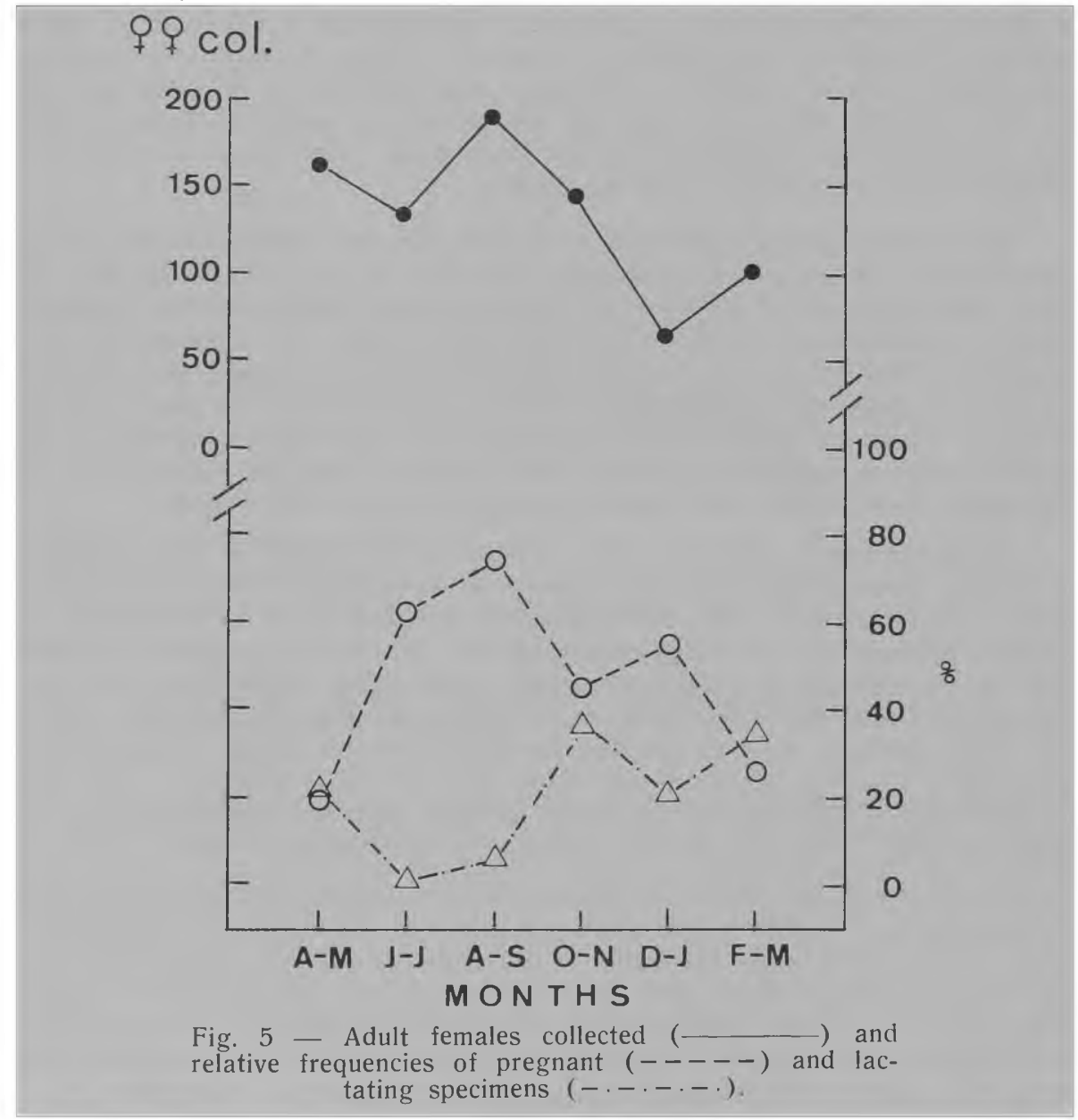

Among the animals studied, one female of Chrotopterus $a$. australis, collected pregnant and maintained isolated in captivity, gave birth to one young, a female, after 99 days. The observed maximum frequencies for 
females with incipient pregnancy compared with those in final stages of gestation and lactating specimens (Fig. 4 and 5) suggest, at least as an estimate of the mean for the species in question, a gestation period greater than three and one half months.

One young per litter is characteristic for the family Phyllostomidae; however, in Macrotus californicus a female with two embryos was confirmed (Cockrum, 1955: 489). In the present study, we verified conditions which can suggest the appearance of more than a single embryo. In the species Carollia $p$ perspicillata and Vampyrops lineatus a developed corpus luteum was found in each ovary in non-pregnant adult females collected in May The same condition was observed in Phyllostomus $d$. discolor, collected in June, which revealed a single implanted embryo. In three females of Artibeus $j$. planirostris obtained in December, March, and April we verified, respectively, that: one young revealed one follicle with three oocytes in one ovary (Fig. 6); a non-pregnant adult with a follicle with 2 oocytes and one with several follicles with 2 oocytes (Fig. 7). Among young females of Artibeus l. lituratus we noted: one follicle with two oocytes in a specimen collected in January, several follicles with two and one with three oocytes in a specimen captured in April and one follicle with two oocytes in a specimen obtained in May.

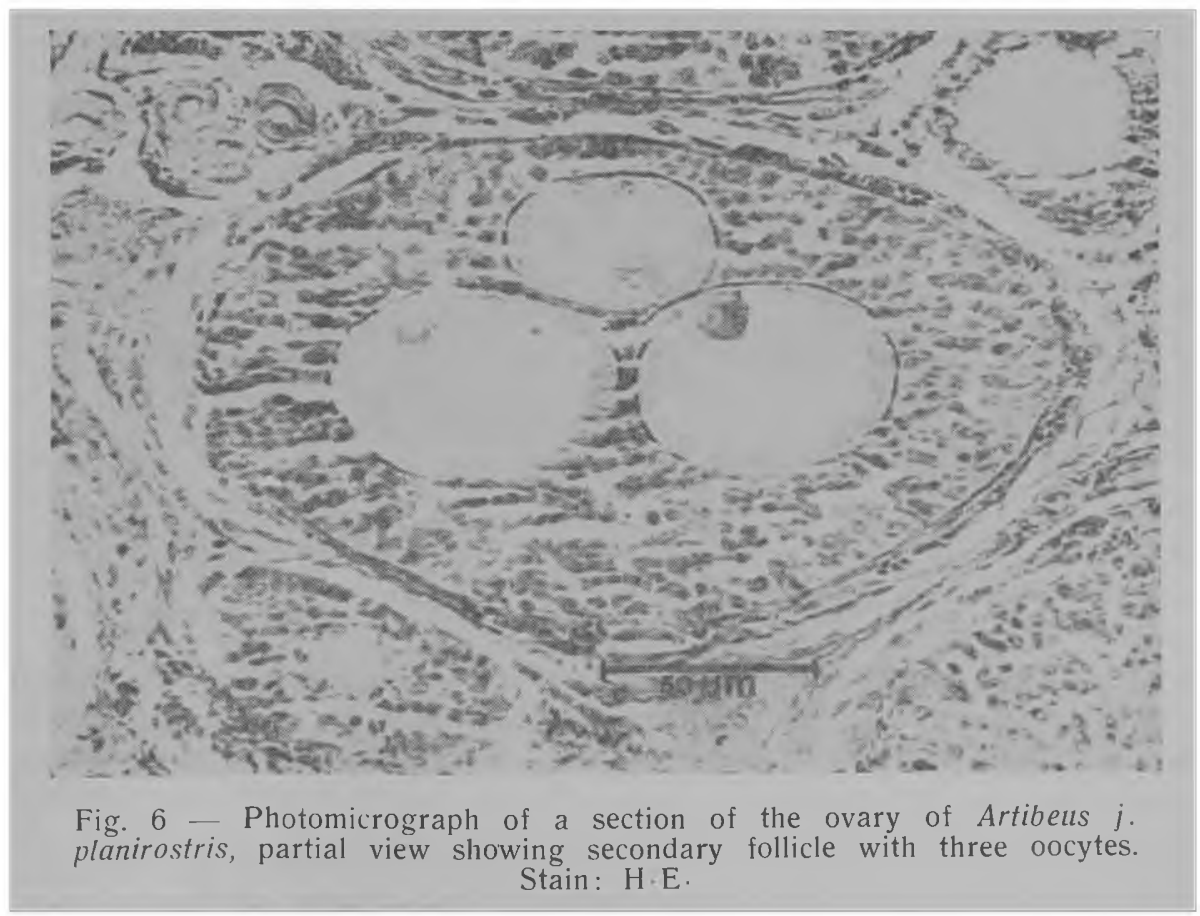

According to Wimsatt and Trapido (1952: 424), biovular follicles are occasional in Desmodus rotundus and one specimen with a single implanted embryo had two functional and identically developed corpora lutea in the ovary. According to those authors, it is reasonable to suppose that two ova were released, but one did not develop or was reab- 
sorbed early in its development. In Noctilio l. minor - Noctilionidae, a single young results from each pregnancy and a single corpus luteum is usual; a corpus luteum was occasionally found in each ovary (Anderson and Wimsatt, 1963: 186). In Artibeus l. palmarum only a single corpus luteum was found in 40 specimens which had a single implantation or embryo. Apparently, the number of young was limited by the reduction in the number of ova released and at estrus only one ovum was released (Tamsitt and Valdivieso, 1965a: 160).

Of the 387 pregnant females examined, we observed only one embryo per pregnancy and, owing to the similarity of the cases, the conclusions arrived at by Wimsatt and Trapido (1952: 424) appear to also apply here.

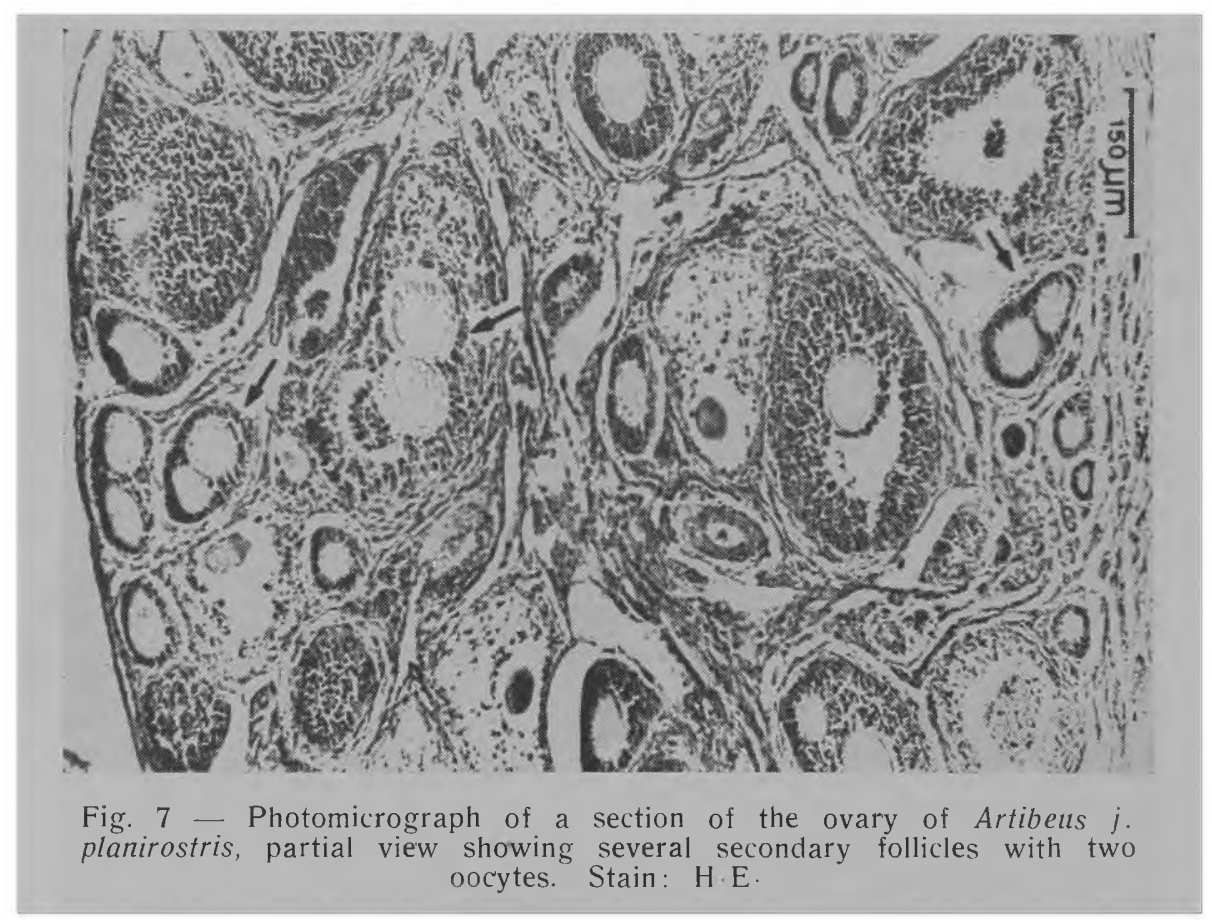

The development of the testes and ovaries is not necessarily associated with body growth or with the acquisition of adult fur, as in Artibeus $l$. palmarum (Tamsitt and Valdivieso, 1965: 152; 1965a: 161). In males, physical development preceds sexual maturity. Animals with non-ossified metaphyses did not reveal releasable spermatozoa in the epididymis. In relation to body growth, many of these specimens exhibited larger forearms than adult males with full sexual activity. The weights, on the average, were always less than the weights of males with spermatozoa. Among the young females with non-ossified metaphyses, ovaries in different functional conditions were observed, from those in a state of rest to those with follicles in all stages of development. Among these females, ovaries with vesicular follicles were noted in Phyllostomus $h$. hastatus in January; 
Glossophaga $s$. soricina in March and April; Carollia $p$ perspicillata in March; Artibeus $l$. lituratus in May and June and with a developed corpus luteum, in Chiroderma $v$ villosum in May. Females may precede males in terms of sexual maturity and, despite being physically immature, are nevertheless apparently able to become impregnated. However, if such cases really do occur, they are rare since of all the pregnant and lactating females examined, a total of 499 , exhibited ossified metaphyses.

\section{CONCLUSIONS}

In the majority of the Phyllostomidae studied, the sexual process is continuous throughout the year, which is also supported by the occurrence of sexually mature males (group III) throughout the year.

There are two primary and partially delimited periods of reproduction. A principal one, from June to October-November, with a greater incidence of females in incipient pregnancy in June-July and births in OctoberNovember, and a secondary period, in continuity with the first, with births principally in February-March.

The months of February to May correspond to the period of lowest incidence of gestation (below 30\%), in which the majority of the females obtained are lactating, non-pregant adults and young.

The incidence of gestations increases from the middle of the cold, dry season in June-July and remains above $40 \%$ until the middle of the warm, rainy season in December-January. The pregnant females collected in the months of February-March are, principally, specimens whose gestations are nearing completion.

The greatest incidences of lactating females occur in the periods of October-Nevember and February-March, with an absence or minimal percentage of lactating females in the colder and drier months of June and July.

In general females predominate, except in the species Phyllostomus $h$. hastatus and Glossophaga s. soricina. Of all individuals collected, $53.02 \%$ were female and $46.98 \%$ male.

\section{ACKNOWLEDGEMENTS}

We are grateful to the professors of the Faculdade de Filosofia, Ciências e Letras de São José do Rio Preto, Dr. Luiz Dino Vizotto, for his guidance and motivation; Dr. Celso Abbade Mourão, for his suggestions and support, and Dr. James R. Coleman, for his help with the manuscript; to the professors of the Faculdade Regional de Medicina de São José do Rio Preto, Dr. Jorge Paulete and Suzana Scaglia de Paulete, for making the serial slides and assisting in their interpretation; to Dr. Brian McNab, of the University of Florida and Dr. H. B. House, of the Bronx Park (N. Y Zoological Society), for his help in obtaining part of the necessary bibliography; to the Fundação de Amparo à Pesquisa do Estado de São Paulo, for financing collecting trips and laboratory equipment and material. 


\section{REFERENCES}

ALMEIDA, F.F.M. - 1964 - Fundamentos geológicos do relêvo paulista. Geologia do Estado de São Paulo. Bolm. Inst. geogr. geol. Est. S. Paulo, 41: 167-263.

ANDERSON, J.W and W.A. WIMSATT - 1963 - Placentacion and fetal membranes of the Central American Noctilionid bat, Noctilio labialis minor. Amer. J. Anat., 112: 181-201.

ARID, F.M. - 1967 - A Formação Bauru na região Norte-Ocidental do Estado de São Paulo. Fac. Filos. Ciênc. Letr. S. J. Rio Preto. Geociências, 1: 1-126.

BARCHA, S.F and F.M. ARID - 1971 - Estudo da Evapotranspiração na regiāo Norte-Ocidental do Estado de São Paulo. Revta. Ciênc. Fac. Ciênc. Letr. Votuporanga, 1: 97-122.

COCKRUM, E.L. - 1955 - Reproduction in North American bats. Trans. Kans. Acad. Sci., 58: 487-511.

DWYER, P.D. - 1970 - Latitude and breeding season in a polyestrus species of Myotis. J. Mammal., 51(2): 405-410.

HAMLETT, G.W.D. - 1935 - Breeding habits of the Phyllostomid bats. J. Mammal., 16: $146-147$.

MARINIS, G. de and P.N. CAMARGO - 1966 - Problemas fitogeográficos de São José do Rio Preto, Estado de São Paulo, Brasil. Anais Esc. sup. Agric. "Luiz de Queiroz", 23: $129-136$.

MATTHEWS, L.H. - 1941 - Notes on the genitalia and reproduction of some African bats. Proc. zool. Soc. Lond., ser. B, 111: 289-346.

PERACCHI, A.L. - 1968 - Sobre os hábitos de "Histiotus velatus" (Geoggroy, 1824) (Chiroptera, Vespertilionidae). Revta. bras. Biol., 28(4): 469-473.

PIRLOT, P. - 1967 - Periodicité de la reproduction chez les Chiroptères neo-tropicaux. Mammalia, 31(3): 361-366.

ROMARIZ, D.A. - 1955 - A vegetação original da Bacia Paraná-Uruguai (Primeiros estudos). Comunções. Int. Bacia Paraná-Uruguai, 1: 111-131.

SETzER, J. - 1966 - Atlas climático e ecológico do Estado de São Paulo. Com. Int. Bacia Paranã-Uruguai (em colaboração com as Centrais Elétricas de São Paulo CESP) S. Paulo, 1-61.

TAMSITT, J.R. and C.A. MEJIA - 1962 - The reproductive status of a population of the neotropical bat, Artibeus jamaicensis, at Providencia. Caribb. J. Sci., 2: 139-144.

TAMSITT, J.R. and D. VALDIVIESO - 1963 - Condicion reproductora de una colonia ecuatoriana del murciélago myotis negro, Myotis nigricans nigricans (Familia Vespertilionidae). Caribb. J. Sci., 3 (1):

TAMSITT, J.R. and D. VALDIVIESO - 1963a - Reproductive cycle of the big fruiteating bat, Artibeus lituratus Olfers. Nature, 198: 104.

TAMSITT, J.R. and D. VALDIVIESO - 1964 - Informations sur la reproduction des Cheiroptères phyllostomides de Colombie. Mammalia, 28(3): 397-402.

TAMSITT, J.R. and D. VALDIVIESO - 1965 - The male reproductive cycle of the bat Artibeus lituratus. Am. Midl. Nat., 73: 150-160.

TAMSITT, J.R. and D. VALDIVIESO - 1965a - Reproduction of the female big fruit-eating bat, Artibeus lituratus palmarum, in Colombia. Caribb. J. Sci., 5(3-4): 157-166.

WILSON, D.E. and J.S. FINDLEY - 1970 - Reproductive cycle of a Neotropical insectivorus bat, Myotis nigricans. Nature,"225 (5238): 1155.

WIMSATT, W.A. and H. TRAPIDO - 1952 - Reproduction and the female reproductive cycle in the tropical american vampire bat, Desmodus rotundus murinus. Am. J. Anat., 91(3): 415-446. 